BNL-114103-2017-JA

\title{
Magnesium-Ion Battery-Relevant Electrochemistry of MgMn2O4: Crystallite Size Effects and the Notable Role of Electrolyte Water Content
}

\author{
Jiefu Yin, Alexander B. Brady, Esther S. Takeuchi, \\ Amy C. Marschilok and Kenneth J. Takeuchi
}

Submitted to Chemical Communications

April 4, 2017

\author{
Energy and Photon Sciences Directorate \\ Brookhaven National Laboratory
}

\author{
U.S. Department of Energy \\ USDOE Office of Science (SC), \\ Basic Energy Sciences (BES) (SC-22)
}

Notice: This manuscript has been co-authored by employees of Brookhaven Science Associates, LLC under Contract No. DE-SC0012704 with the U.S. Department of Energy. The publisher by accepting the manuscript for publication acknowledges that the United States Government retains a non-exclusive, paid-up, irrevocable, world-wide license to publish or reproduce the published form of this manuscript, or allow others to do so, for United States Government purposes. 


\section{DISCLAIMER}

This report was prepared as an account of work sponsored by an agency of the United States Government. Neither the United States Government nor any agency thereof, nor any of their employees, nor any of their contractors, subcontractors, or their employees, makes any warranty, express or implied, or assumes any legal liability or responsibility for the accuracy, completeness, or any third party's use or the results of such use of any information, apparatus, product, or process disclosed, or represents that its use would not infringe privately owned rights. Reference herein to any specific commercial product, process, or service by trade name, trademark, manufacturer, or otherwise, does not necessarily constitute or imply its endorsement, recommendation, or favoring by the United States Government or any agency thereof or its contractors or subcontractors. The views and opinions of authors expressed herein do not necessarily state or reflect those of the United States Government or any agency thereof. 


\section{Journal Name}

\section{COMMUNICATION}

\section{Magnesium-Ion Battery-Relevant Electrochemistry of $\mathrm{MgMn}_{2} \mathrm{O}_{4}$ : Crystallite Size Effects and the Notable Role of Electrolyte Water Content}

Received 00th January 20xx Accepted 00th January 20xx

DOI: $10.1039 / \times 0 \times x 00000 x$

\author{
Jiefu Yin, ${ }^{a}$ Alexander B. Brady, ${ }^{a}$ Esther S. Takeuchi, ${ }^{a, b, c} *$ Amy C. Marschilok, ${ }^{a, b *}$ Kenneth J. Takeuchi ${ }^{a, b} *$
}

www.rsc.org/

$\mathrm{MgMn}_{2} \mathrm{O}_{4}$ nanoparticles with crystallite sizes of 11 (MMO-1) and $31 \mathrm{~nm}$ (MMO-2) were synthesized and their magnesium-ion battery-relevant electrochemistry was investigated. MMO-1 delivered an initial capacity of $220 \mathrm{mAh} / \mathrm{g}(678 \mathrm{mWh} / \mathrm{g})$. Electrolyte water content had a profound effect on cycle retention.

Magnesium-ion $\left(\mathrm{Mg}^{2+}\right)$ batteries (MIB) offer the opportunity for high volumetric capacity due to the dicationic nature of $\mathrm{Mg}^{2+}$ (3832 $\mathrm{mAh} / \mathrm{cm}^{3}$ of $\mathrm{Mg}$ ). However, the bivalency of $\mathrm{Mg}^{2+}$ with its small cation size results in very strong $\mathrm{Mg}^{2+}$ - anion electrostatic attractions within the cathode lattice, and slow $\mathrm{Mg}^{2+}$ diffusion and exchange. ${ }^{1,2}$ Thus, an important challenge is identification of cathodes capable of faster $\mathrm{Mg}^{2+}$ (de)insertion, ${ }^{3}$ and electrolytes to facilitate $\mathrm{Mg}^{2+}$ (de)solvation.

Chevrel phase materials which employ sulfide anions, such as $\mathrm{Mg}_{\mathrm{x}} \mathrm{Mo}_{3} \mathrm{~S}_{4}$, have been previously reported as cathodes for $\mathrm{MIB}{ }^{4-6}$ capable of providing 2000 cycles at $100 \%$ depth of discharge with a capacity fade $<15 \%{ }^{4}$ While the weaker $\mathrm{Mg}^{2+}$ sulfide electrostatic attractions facilitate $\mathrm{Mg}^{2+}$ (de)insertion, the working voltage for these materials of approximately $1.5 \mathrm{~V}$ (vs $\mathrm{Mg}^{2+} / \mathrm{Mg}$ ), may be considered low for some applications.

Metal oxides have also been studied as MIB cathode materials. $^{7-9}$ Although the oxide anions will contribute to a higher working voltage relative to sulfide-containing materials, there will also be strong $\mathrm{Mg}^{2+}$ - oxide electrostatic attractions which may kinetically impede $\mathrm{Mg}^{2+}$ de-insertion with metal oxide materials. To address this issue, water added to the electrolyte remains in the $\mathrm{Mg}^{2+}$ coordination sphere both in solution and when $\mathrm{Mg}^{2+}$ insertion occurs. Water bonded to $\mathrm{Mg}^{2+}$ is claimed to "shield" the $\mathrm{Mg}^{2+}$ upon, thus reducing the

\footnotetext{
a. Department of Chemistry, Stony Brook University, Stony Brook, NY 11794

${ }^{b .}$ Department of Materials Science and Engineering, Stony Brook University, Stony Brook, NY 11794

Energy Sciences Directorate, Brookhaven National Laboratory, Upton, NY 11973 *corresponding: $\quad$ esther.takeuchi@stonybrook.edu amy.marschilok@stonybrook.edu (ACM), kenneth.takeuchi.1@stonybrook.edu (KJT)

Electronic Supplementary Information (ESI) available: [Experimental details, Rietveld refinement results, TGA, XRD of electrodes after cycling test, and capacity calculated from cyclic voltammetry tests.]. See DOI: 10.1039/x0xx00000x
}

$\mathrm{Mg}^{2+}$ - oxide electrostatic attraction. ${ }^{10-12}$ The preceding voltage and cycle life hypotheses concerning $\mathrm{Mg}^{2+}$ battery-relevant electrochemistry were consistent in principle to our previous study of vanadium oxide xerogels $\left(\mathrm{Mg}_{\mathrm{x}} \mathrm{V}_{2} \mathrm{O}_{5} \cdot \mathrm{nH}_{2} \mathrm{O}\right) .{ }^{13,14}$

In addition to vanadium oxides, manganese oxides are another promising family of MIB cathode materials. Manganese oxides are a structurally rich class of materials; providing layered, tunneled, or spinel structured materials. ${ }^{15-17}$ In the presence of water, $\alpha-\mathrm{MnO}_{2}$ structured silver hollandite or potassium cryptomelane $\left(\mathrm{M}_{\mathrm{x}} \mathrm{Mn}_{8} \mathrm{O}_{16}, \mathrm{M}=\mathrm{Ag}\right.$ or $\left.\mathrm{K}\right)$ can deliver $180 \mathrm{mAh} / \mathrm{g}$ capacity where $\mathrm{Mg}^{2+}$ ion (de)insertion was demonstrated in $\mathrm{K}_{\mathrm{x}} \mathrm{Mn}_{8} \mathrm{O}_{16}$ and $\mathrm{Ag}_{\mathrm{x}} \mathrm{Mn}_{8} \mathrm{O}_{16} .{ }^{18}$ When cycled in anhydrous organo-aluminate electrolyte, $\mathrm{K}-\alpha-\mathrm{MnO}_{2}$ showed high initial capacity of $300 \mathrm{mAh} / \mathrm{g}$ but significant fade to 150 $\mathrm{mAh} / \mathrm{g}$ at the $2^{\text {nd }}$ cycle, with additional capacity loss upon subsequent cycling. ${ }^{19}$ Scanning tunneling electron microscope (STEM) and X-ray absorption spectroscopy (XAS) detected formation of an amorphous layer ( $\mathrm{MgO}$ and $\mathrm{Mn}_{2} \mathrm{O}_{3}$ ) on the $\alpha$ $\mathrm{MnO}_{2}$ surface after magnesiation, indicating a conversion reaction rather than an insertion process, ${ }^{20}$ consistent with their theoretical predictions. ${ }^{21}$ In layered birnessite, water in the electrolyte also plays an important role: an irreversible structural conversion to spinel was observed upon $\mathrm{Mg}^{2+}$ insertion into $\mathrm{MnO}_{2} \cdot 0.94 \mathrm{H}_{2} \mathrm{O}$ in dry electrolyte, yet the (de)insertion of $\mathrm{Mg}^{2+}$ in an electrolyte containing water was reversible with retention of the layered structure. ${ }^{11,} 22,23$ Water was also shown to improve the electrochemistry of electrodeposited amorphous $\mathrm{MnO}_{2}$ nanorods, proportional to the concentration of water in electrolyte. ${ }^{10}$

Spinel magnesium manganese oxide $\left(\mathrm{MgMn}_{2} \mathrm{O}_{4}\right)$ has a tetragonal structure different from the typical cubic structure of spinels, due to distortion induced by the strong Jahn-Teller effect of $\mathrm{Mn}^{3+} \cdot{ }^{24-26}$ A cation migration is often observed in $\mathrm{MgMn}_{2} \mathrm{O}_{4}$, in which $\mathrm{Mg}^{2+}$ and $\mathrm{Mn}^{3+}$ exchange positions due to their similar ionic radii $\left(0.63 \AA\right.$ for tetrahedral $\mathrm{Mg}^{2+}$ and 0.72 for octahedral $\mathrm{Mn}^{3+}$, respectively). ${ }^{27}$ The exchange triggers a structural change from tetragonal to cubic, termed an "inversion reaction" 28-31 and is most common under high temperature and high pressure conditions. ${ }^{29,31}$ 
$\mathrm{LiMn}_{2} \mathrm{O}_{4}$ is a successful cathode material in lithium ion batteries, where the nano-sized material exhibits excellent rate capability. ${ }^{32,33} \mathrm{LiMn}_{2} \mathrm{O}_{4}$ has also been applied in a hybrid battery with $\mathrm{Mg}$ metal anode, the initial discharge capacity is over $100 \mathrm{mAh} / \mathrm{g}$ in both $0.5 \mathrm{M} \mathrm{Mg}(\mathrm{TFSI})_{2}$-LiTFSI/diglyme and $0.25 \mathrm{M} \mathrm{Mg}\left(\mathrm{CB}_{11} \mathrm{H}_{12}\right)_{2}$ based electrolyte systems, ex-situ XRD and XAS demonstrate the $\mathrm{LiMn}_{2} \mathrm{O}_{4}$ is stable during cycling. ${ }^{34}$ Thus, the analogue structure $\mathrm{MgMn}_{2} \mathrm{O}_{4}$, has been of interest as a potential cathode material for $\mathrm{MIB}^{35,}{ }^{36} \mathrm{LiMn}_{2} \mathrm{O}_{4}$ can be converted to $\mathrm{MgMn}_{2} \mathrm{O}_{4}$ in aqueous $\mathrm{Mg}^{2+}$ electrolyte, and the resultant $\mathrm{MgMn}_{2} \mathrm{O}_{4}$ delivered $\sim 40 \mathrm{mAh} / \mathrm{g}$ capacity in aqueous electrolyte. ${ }^{37}$ Chemically synthesized $\mathrm{MgMn}_{2} \mathrm{O}_{4}$ was also studied in aqueous $\mathrm{Mg}^{2+}$ electrolyte, the initial capacity was $\sim 160 \mathrm{mAh} / \mathrm{g} .{ }^{36}$ Unlike the situation in aqueous electrolyte, investigations of $\mathrm{MgMn}_{2} \mathrm{O}_{4}$ in non-aqueous $\mathrm{Mg}^{2+}$ electrolyte have been limited. For a three electrode system utilizing a $\mathrm{Pt}$ reference, a $\mathrm{V}_{2} \mathrm{O}_{5}$ electrode, and an $\mathrm{MgMn}_{2} \mathrm{O}_{4}$ electrode in an electrolyte of $0.5 \mathrm{M} \mathrm{Mg}\left(\mathrm{ClO}_{4}\right)_{2}$ in EC : DEC (50:50), a discharge capacity of $120 \mathrm{mAh} / \mathrm{g}$ can be delivered. ${ }^{36}$ Another example was studied in an electrolyte of $0.2 \mathrm{M} \mathrm{Mg}\left(\mathrm{CH}_{3} \mathrm{COO}\right)_{2} / 0.1 \mathrm{M}$ $\mathrm{AlCl}_{3}$ in PC, $102 \mathrm{mAh} / \mathrm{g}$ capacity can be observed. ${ }^{38}$

Our previous studies have demonstrated strong correlations between crystallite size and electrochemical performance in manganese oxides. We present here the first systematic study of $\mathrm{MgMn}_{2} \mathrm{O}_{4}$ as a cathode material in MIB. The materials were synthesized by a modified Pechini method, and annealing temperature was used to control crystallite size of the products. The electrochemistry of $11 \mathrm{~nm} \mathrm{MMO-1}$ and 31 $\mathrm{nm}$ MMO-2 was studied in magnesium based electrolyte with and without added water in the electrolyte. Higher capacity was delivered by the smaller crystallite sized material and capacity retention increased in the presence of water. While hydrous electrolytes may be impractical for batteries with $\mathrm{Mg}$ metal anodes, it is anticipated that such electrolytes may be viable in Mg-ion batteries with alternative anodes, such as $\mathrm{Mg}_{3} \mathrm{Bi}_{2}{ }^{39}$

The as-synthesized $\mathrm{MgMn}_{2} \mathrm{O}_{4}$ samples were characterized by synchrotron X-ray powder diffraction (XPD). Fig. 1 shows the Rietveld refinement of XPD diffraction patterns. Both MMO-1 and MMO-2 can be fitted to tetragonal spinel $\mathrm{MgMn}_{2} \mathrm{O}_{4}$ structure with space group of I 41/amd. Both samples show reasonable $\mathrm{R}_{\mathrm{wp}}$ values: MMO-1 $(9.30 \%)$ and MMO-2 (7.42 \%). The fitted crystal structure parameters and atom arrangements are shown in Table S1 and Table S2. In the tetragonal structure, $\mathrm{Mg}^{2+}$ is in the tetragonal site and $\mathrm{Mn}^{3+}$ occupies the octahedral site. A minor structural inversion has been reported from the rearrangement of tetragonal $\mathrm{Mn}^{3+}$ and octahedral $\mathrm{Mg}^{2+} .^{28}$ In our case, very low inversion was observed (0.07 \% for MMO-1 and 0.70\% for MMO-2). MMO-1 (annealed at $400^{\circ} \mathrm{C}$ ) displayed significant diffraction peak broadening, while MMO-2 (annealed at $550^{\circ} \mathrm{C}$ ) showed sharper and more intense peaks. The crystallite size values calculated from Rietveld refinement were $13 \mathrm{~nm}$ for MMO-1 and $42 \mathrm{~nm}$ for MMO-2. Using the Scherrer equation and the (101) peak at $18.15^{\circ}$ to calculate crystallite size of the samples gave values of $11 \mathrm{~nm}$ for MMO-1 and $31 \mathrm{~nm}$ for MMO-2, which are used to describe the materials throughout this manuscript. Transmission electron microscopy (TEM) images of MMO-1 and MMO-2, Fig. 2, indicate the MMO-1 nanoparticles were $\sim 10 \mathrm{~nm}$ size, while the MMO-2 particles
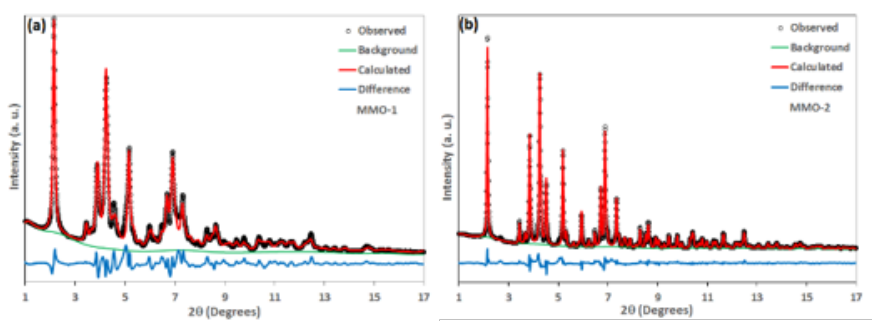

were in $20-50 \mathrm{~nm}$ range consistent with crystallite size values estimated from diffraction.

Fig. 1 Synchrotron X-ray powder diffraction (XPD) and Rietveld analysis of as-synthesized $\mathrm{MgMn}_{2} \mathrm{O}_{4}$ samples: (a) MMO-1, (b) MMO-2.

Fig. 2 TEM images of (a) MMO-1 and (b) MMO-2.

The $\mathrm{Mg} / \mathrm{Mn}$ ratio of each sample was evaluated using inductively coupled plasma-optical emission spectroscopy (ICPOES) yielding a formula of $\mathrm{MgMn}_{2} \mathrm{O}_{4}$ for both MMO-1 and MMO-2. Thermogravimetric analysis (TGA) of the precursor, Fig. S1, showed $70 \%$ weight loss upon heating to $580{ }^{\circ} \mathrm{C}$. A rapid weight loss occurred at $220-350{ }^{\circ} \mathrm{C}$ with minor weight loss between $350-580{ }^{\circ} \mathrm{C}$. The synthesized MMO-1 lost $5.8 \%$ and MMO-2 lost $1.8 \%$ weight upon heating to $800^{\circ} \mathrm{C}$,

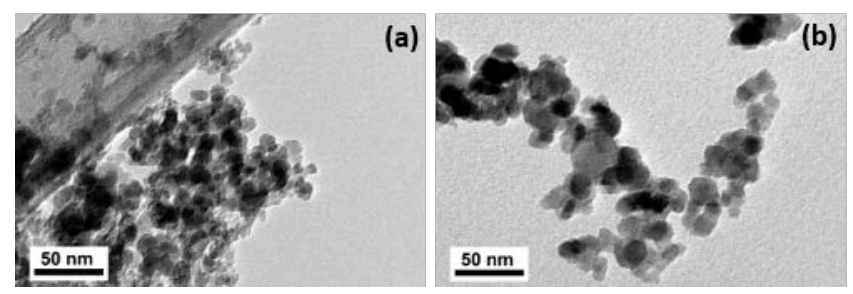

consistent with $\mathrm{MgMn}_{2} \mathrm{O}_{4} \cdot 0.7 \mathrm{H}_{2} \mathrm{O}$ and $\mathrm{MgMn}_{2} \mathrm{O}_{4} \cdot 0.2 \mathrm{H}_{2} \mathrm{O}$, respectively. The BET surface area for MMO-1 was $73 \mathrm{~m}^{2} / \mathrm{g}$, and MMO-2 was $24 \mathrm{~m}^{2} / \mathrm{g}$.

The electrochemistry of as-synthesized $\mathrm{MgMn}_{2} \mathrm{O}_{4}$ samples $\left(3.9 \mathrm{mg} / \mathrm{cm}^{2}\right.$ mass loading on electrodes) was studied in two $\mathrm{Mg}^{2+}$ electrolytes: $0.5 \mathrm{M} \mathrm{Mg}(\mathrm{TFSI})_{2}$ in acetonitrile/0.5 M dipropylene glycol dimethyl ether (anhydrous) and $0.5 \mathrm{M}$ $\mathrm{Mg}(\mathrm{TFSI})_{2}+3 \mathrm{M} \mathrm{H}_{2} \mathrm{O}$ in acetonitrile/0.5 M dipropylene glycol dimethyl ether (hydrous). The cyclic voltammetry (CV) curves of MMO-1 and MMO-2 in both electrolytes are shown in Fig. 3. In the anhydrous electrolyte, MMO-1 has redox potentials of $0 \mathrm{~V}\left(\mathrm{E}_{\mathrm{pc}}\right) / 0.7 \mathrm{~V}\left(\mathrm{E}_{\mathrm{pa}}\right)$, corresponding to the redox of $\mathrm{Mn}^{3+} /$ $\mathrm{Mn}^{4+}$. MMO-2 has similar $\mathrm{E}_{\mathrm{pc}}$ and a slightly higher $\mathrm{E}_{\mathrm{pa}}$ of $0.8 \mathrm{~V}$, Fig. 3a. The peak current of $11 \mathrm{~nm}$ MMO-1 is $\sim 4$ times higher than that of the $31 \mathrm{~nm}$ MMO-2, which indicates that the crystallite size has a significant influence on the $\mathrm{Mg}^{2+}$ (de)insertion into the $\mathrm{MgMn}_{2} \mathrm{O}_{4}$ structure. It is notable that no significant decrease in peak current was observed on either sample over $4 \mathrm{CV}$ cycles, suggesting reasonable reversibility of the material. In the electrolyte containing $3 \mathrm{M} \mathrm{H}_{2} \mathrm{O}$, the $\mathrm{E}_{\mathrm{pc}}$ of MMO-1 shifts to $-0.1 \mathrm{~V}$ and no $E_{\mathrm{pa}}$ can be observed. MMO-2 displays $0.07 \vee\left(E_{p c}\right) / 0.6 \vee\left(E_{p a}\right)$. The crystallite size affects electrochemistry in the hydrous electrolyte where MMO-1 has $\sim 3$ times higher peak current than MMO-2, and the $\mathrm{Mg}^{2+}$ 
(de)insertion is reversible without significant change in current over 4 cycles.

Galvanostatic charge-discharge testing was used and the initial charge-discharge voltage curves in both anhydrous and hydrous electrolytes at $0.1 \mathrm{C}$ are shown in Fig. $4 \mathrm{a}$, displaying a sloping voltage profile with an average working potential of $0.02 \mathrm{~V} \mathrm{vs} \mathrm{Ag}^{+} / \mathrm{Ag}$ (3.07 $\mathrm{V}$ vs $\mathrm{Mg}^{2+} / \mathrm{Mg}$ ). MMO-1 delivered 220 $\mathrm{mAh} / \mathrm{g}$ capacity $\left(0.81 \mathrm{Mg}^{2+}\right.$ insertion) at $1^{\text {st }}$ discharge in both electrolytes, however, MMO-2 delivered only $70 \mathrm{mAh} / \mathrm{g}(0.26$ $\mathrm{Mg}^{2+}$ insertion). Fig. 4b displays the cycling results of MMO-1 and MMO-2. Although the discharge capacity at the initial cycles was similar in both electrolytes, the $\mathrm{MgMn}_{2} \mathrm{O}_{4}$ samples showed more significant capacity decrease with cycling in dry electrolyte. MMO-1 decreased in delivered capacity from the $1^{\text {st }}$ cycle to the $40^{\text {th }}$ cycle, where the final capacity retention was $28 \%$ (63 mAh/g of $220 \mathrm{mAh} / \mathrm{g}$ ), MMO-2 lost $42 \%$ capacity in the same electrolyte (41 mAh/g of $71 \mathrm{mAh} / \mathrm{g})$. The reversibility of $\mathrm{MgMn}_{2} \mathrm{O}_{4}$ was significantly improved by the addition of water, MMO-1 delivered $162 \mathrm{mAh} / \mathrm{g}$ at the $40^{\text {th }}$ cycle, corresponding to $74 \%$ capacity retention, while no significant capacity decrease was observed for MMO-2.

Notably, the energy density of MMO-1 could reach 678 $\mathrm{mWh} / \mathrm{g}$, significantly higher than the energy density of Chevrel phase materials ( $130 \mathrm{mWh} / \mathrm{g})^{4}$ or magnesium vanadium oxide xerogels $(420 \mathrm{mWh} / \mathrm{g}) .{ }^{14}$ The high energy delivery of MMO-1 results from the high working voltage and high capacity, making the $\mathrm{MgMn}_{2} \mathrm{O}_{4}$ a promising MIB cathode material. Rate capability was studied in hydrous and anhydrous electrolytes (Fig. 4c): at 0.5, 1.0, and 2.0C, MMO-1 delivered 93, 70, and $50 \%$ of its 0.1 C capacity, respectively, and its capacity fully recovered over the last five $0.1 \mathrm{C}$ cycles in hydrous electrolyte, while in anhydrous electrolyte only 40,28 , and $16 \%$ of its $0.1 \mathrm{C}$ capacity was delivered at $0.5 \mathrm{C}, 1.0 \mathrm{C}$, and $2.0 \mathrm{C}$, respectively and only $63 \%$ capacity was recovered at last five $0.1 \mathrm{C}$ cycles in anhydrous electrolyte. At the higher rates of $0.5,1.0$, and $2.0 \mathrm{C}$ MMO-2 delivered 63,51 , and $27 \%$ of its capacity at $0.1 \mathrm{C}$, where $70 \%$ capacity was retained over the last five $0.1 \mathrm{C}$ cycles in hydrous electrolyte, and the capacity retention in anhydrous electrolyte was slightly lower at each rate affirming the crucial role of water in reversibility and rate capability.
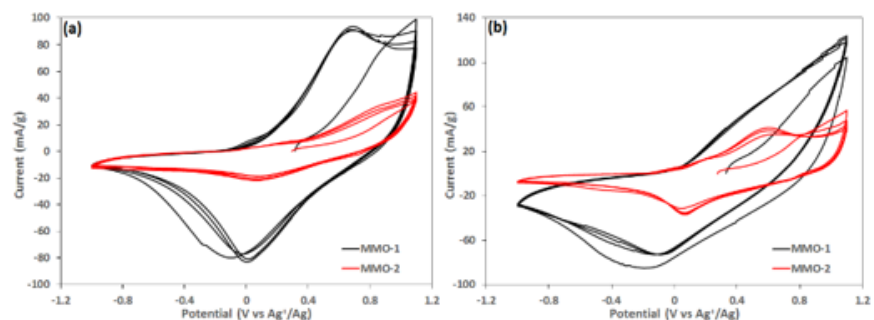

Fig. 3 Cyclic voltammetry test of MMO-1 (11 nm) and MMO-2 (31 $\mathrm{nm}$ ) in a) $0.5 \mathrm{M} \mathrm{Mg}(\mathrm{TFSI})_{2}$ in acetonitrile/0.5 $\mathrm{M}$ dipropylene glycol dimethyl ether, b) $0.5 \mathrm{M} \mathrm{Mg}(\text { TFSI })_{2}+3 \mathrm{M} \mathrm{H}_{2} \mathrm{O}$ in acetonitrile/0.5 M dipropylene glycol dimethyl ether electrolyte. Scan rate: $0.1 \mathrm{mV} / \mathrm{s}$.

The higher discharge capacity and better rate capability of MMO-1 can be attributed to its smaller crystallite size and higher surface area where the ion diffusion path for $\mathrm{Mg}^{2+}$ is shorter. The polarization was lower compared to the $31 \mathrm{~nm}$ MMO-2, ${ }^{23}$ making $\mathrm{Mg}^{2+}$ diffusion more facile in MMO-1. Water additive in the electrolyte improved the reversibility of $\mathrm{Mg}^{2+}$ (de)insertion into the structure. It has been demonstrated that water facilitates the dissociation of $\mathrm{Mg}^{2+}$ from $\mathrm{TFSI}^{-}$, resulting in higher free $\mathrm{Mg}^{2+}$ in electrolyte, and water can also reduce the $\mathrm{Mg}^{2+}$ de-solvation energy, which facilitates the subtraction of $\mathrm{Mg}^{2+}$ from $\mathrm{MgMn}_{2} \mathrm{O}_{4}$ structure in charge process. ${ }^{40,41} \mathrm{Mn}$ dissolution is thought to be a crucial drawback in spinel $\mathrm{LiMn}_{2} \mathrm{O}_{4}{ }^{42,}{ }^{43}$ and $\mathrm{MgMn}_{2} \mathrm{O}_{4}$ is considered to have the same problem, since all the $\mathrm{Mn}$ sites are in +3 oxidation state. $3.2 \%$ $\mathrm{Mn}$ dissolution was reported from $\mathrm{LiMn}_{2} \mathrm{O}_{4}$ in $\mathrm{LiPF}_{6}$ electrolyte. ${ }^{42}$ In this case, no measurable dissolution of $\mathrm{Mn}^{\mathrm{n}+}$ could be detected in either MMO-1 and MMO-2 after soaking in both hydrous and anhydrous $\mathrm{Mg}^{2+}$ electrolyte for 10 days, possibly due to the absence of free LiF in our electrolyte.
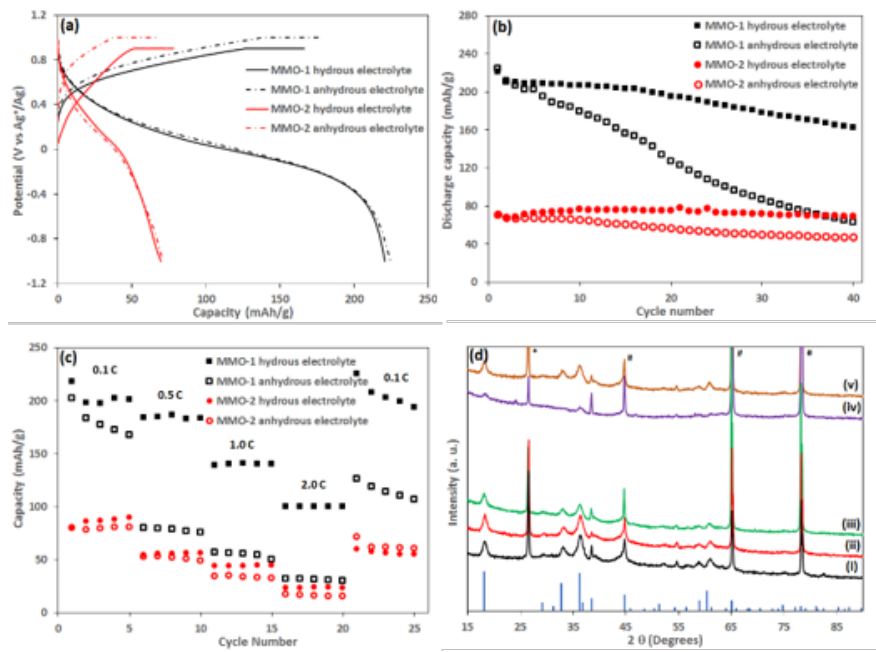

Fig. 4 (a) $1^{\text {st }}$ cycle voltage curve (b) cycle no. vs. discharge capacity and (c) rate capability of MMO-1 and MMO-2 in $0.5 \mathrm{M} \mathrm{Mg}(\mathrm{TFSI})_{2}$ in acetonitrile/0.5 $\mathrm{M}$ dipropylene glycol dimethyl ether with or without water. (d) X-ray diffraction of MMO-1 electrodes: (i) as-prepared; after (ii) $1^{\text {st }}$ charge and (iii) $1^{\text {st }}$ discharge in hydrous electrolyte; after (iv) $1^{\text {st }}$ charge and (v) $1^{\text {st }}$ discharge in anhydrous electrolyte. *graphite, \#Al foil Since $\mathrm{Mg}^{2+}$ has high charge density, its insertion can result in significant structural changes or decomposition of the cathode lattice. For example amorphous $\mathrm{MgO}$ and $\mathrm{Mn}_{2} \mathrm{O}_{3}$ were observed in the $\mathrm{Mg}^{2+}$ inserted $\alpha-\mathrm{MnO}_{2}$ structure. ${ }^{20}$ In order to study the structural stability of $\mathrm{MgMn}_{2} \mathrm{O}_{4}$, the electrodes of MMO-1 were recollected after $1^{\text {st }}$ charge, $1^{\text {st }}$ discharge in hydrous and anhydrous electrolyte, and then tested on XRD, Fig. 4c. MMO-1 kept the spinel structure after the $1^{\text {st }}$ charge in hydrous electrolyte \& discharge in both electrolytes, where no obvious peak shift or peak intensity decrease was observed. However, after the $1^{\text {st }}$ charge in anhydrous electrolyte two new peaks at $24^{\circ}$ and $48^{\circ}$ appeared, indicating less structural stability. Our previous study showed that hollandite structure is more stable upon $\mathrm{Mg}^{2+}$ (de)insertion in hydrous electrolyte, ${ }^{18}$ similar to the results here. The electrodes after 40 cycles were collected and XRD results are in Fig. S2, where the electrode from hydrous electrolyte still shows all characteristic diffraction peaks with slightly lower intensity compared to the as-prepared electrode, while that from anhydrous electrolyte has lower intensity, yet maintains the parent phase indicating a stable structure. 
Spinel $\mathrm{MgMn}_{2} \mathrm{O}_{4}$ was successfully synthesized and the crystallite size was controlled by adjusting annealing temperature. The $11 \mathrm{~nm}$ MMO-1 delivered $220 \mathrm{mAh} / \mathrm{g}$ capacity in both hydrous and anhydrous electrolyte, 3 times higher than the $31 \mathrm{~nm}$ MMO-2. Water addition to the electrolyte was found to play an important role in the reversibility of cathode: the capacity retention of MMO-1 can be improved from $28 \%$ to $74 \%$ in the presence of water. It is worth noting that the spinel structure was stable in $\mathrm{Mg}^{2+}$ electrolyte after cycling, most notably in the water containing electrolyte. This manuscript reports a systematic study of spinel $\mathrm{MgMn}_{2} \mathrm{O}_{4}$ in organic $\mathrm{Mg}^{2+}$ electrolyte, where both crystallite size and water content are shown to be important factors influencing the electrochemistry.

The Center for Mesoscale Transport Properties, an EFRC supported by the U.S. Department of Energy, Office of Science, Basic Energy Sciences, under award \#DE-SC0012673 supported synthesis and characterization. Magnesium electrochemistry was supported by the Department of Energy, Office of Electricity, administered through Sandia National Laboratories, PO \#1275961. Use of the National Synchrotron Light Source II, (XPD) Brookhaven National Lab, was supported by the U.S. Department of Energy, Office of Science, Basic Energy Sciences, Contract No. DE-SC0012704. The authors thank Eric Dooryhee, Milinda Abeykoon and Jianming Bai for help with setup.

\section{Notes and references}

1. N. N. Rajput, X. Qu, N. Sa, A. K. Burrell and K. A. Persson, JACS, 2015, 137, 3411-3420.

2. J. Muldoon, C. B. Bucur, A. G. Oliver, T. Sugimoto, M. Matsui, H. S. Kim, G. D. Allred, J. Zajicek and Y. Kotani, Energy \& Environmental Science, 2012, 5, 5941-5950.

3. M. M. Huie, D. C. Bock, E. S. Takeuchi, A. C. Marschilok and K. J. Takeuchi, Coordination Chemistry Reviews, 2015, 287, 15-27.

4. D. Aurbach, Z. Lu, A. Schechter, Y. Gofer, H. Gizbar, R. Turgeman, Y. Cohen, M. Moshkovich and E. Levi, Nature, 2000, 407, 724-727.

5. E. Levi, E. Lancry, A. Mitelman, D. Aurbach, G. Ceder, D. Morgan and O. Isnard, Chem. Mater., 2006, 18, 5492-5503.

6. F. Murgia, P. Antitomaso, L. Stievano, L. Monconduit and R. Berthelot, J. Solid State Chem., 2016, 242, Part 1, 151-154.

7. S. Rasul, S. Suzuki, S. Yamaguchi and M. Miyayama, Electrochimica Acta, 2012, 82, 243-249.

8. D. Imamura, M. Miyayama, M. Hibino and T. Kudo, J. Electrochem. Soc., 2003, 150, A753-A758.

9. X. C. Du, G. Huang, Y. L. Qin and L. M. Wang, Rsc Advances, 2015, 5, 76352-76355.

10. J. Song, M. Noked, E. Gillette, J. Duay, G. Rubloff and S. B. Lee, Physical Chemistry Chemical Physics, 2015, 17, 5256-5264.

11. K. W. Nam, S. Kim, S. Lee, M. Salama, I. Shterenberg, Y. Gofer, J.S. Kim, E. Yang, C. S. Park, J.-S. Kim, S.-S. Lee, W.-S. Chang, S.-G. Doo, Y. N. Jo, Y. Jung, D. Aurbach and J. W. Choi, Nano Lett., 2015, 15, 4071-4079.

12. G. S. Gautam, P. Canepa, W. D. Richards, R. Malik and G. Ceder, Nano Letters, 2016, 16, 2426-2431.

13. S. H. Lee, R. A. DiLeo, A. C. Marschilok, K. J. Takeuchi and E. S. Takeuchi, Ecs Electrochemistry Letters, 2014, 3, 87-90.
14. J. Yin, C. J. Pelliccione, S. H. Lee, E. S. Takeuchi, K. J. Takeuchi and A. C. Marschilok, J. Electrochem. Soc., 2016, 163, A1941A1943.

15. S. L. Suib, J. Mater. Chem., 2008, 18, 1623-1631.

16. S. L. Suib, Acc. Chem. Res., 2008, 41, 479-487.

17. S. Ching and S. L. Suib, Comments on Inorganic Chemistry, 1997, 19, 263-282.

18. J. Huang, A. S. Poyraz, K. J. Takeuchi, E. S. Takeuchi and A. C. Marschilok, Chem. Commun., 2016, 52, 4088-4091.

19. R. Zhang, X. Yu, K.-W. Nam, C. Ling, T. S. Arthur, W. Song, A. M. Knapp, S. N. Ehrlich, X.-Q. Yang and M. Matsui, Electrochem. Commun., 2012, 23, 110-113.

20. T. S. Arthur, R. Zhang, C. Ling, P.-A. Glans, X. Fan, J. Guo and F. Mizuno, ACS Applied Materials \& Interfaces, 2014, 6, 70047008.

21. C. Ling, R. G. Zhang, T. S. Arthur and F. Mizuno, Chem. Mater., 2015, 27, 5799-5807.

22. X. Q. Sun, V. Duffort, B. L. Mehdi, N. D. Browning and L. F. Nazar, Chemistry of Materials, 2016, 28, 534-542.

23. J. Yin, E. S. Takeuchi, K. J. Takeuchi and A. C. Marschilok, Inorg. Chim. Acta, 2016, 453, 230-237.

24. L. Malavasi, P. Ghigna, G. Chiodelli, G. Maggi and G. Flor, Journal of Solid State Chemistry, 2002, 166, 171-176.

25. L. Malavasi, P. Galinetto, M. C. Mozzati, C. B. Azzoni and G. Flor, Phys. Chem. Chem. Phys., 2002, 4, 3876-3880.

26. L. Malavasi, M. C. Mozzati, G. Chiodelli, C. B. Azzoni and G. Flor, Journal of Materials Science, 2004, 39, 1671-1675.

27. R. D. Shannon and C. T. Prewitt, Acta Crystallographica Section B-Structural Crystallography and Crystal Chemistry, 1969, B 25, 925-\&.

28. J. C. Knight, S. Therese and A. Manthiram, Acs Applied Materials \& Interfaces, 2015, 7, 22953-22961.

29. R. Manaila and P. Pausescu, Phys. Status Solidi, 1965, 9, 385-\&.

30. S. K. Panda and I. H. Jung, J. Am. Ceram. Soc., 2014, 97, 33283340.

31. L. Malavasi, C. Tealdi, G. Flor and M. Amboage, Physical Review B, 2005, 71.

32. H. J. Yue, X. K. Huang, D. P. Lv and Y. Yang, Electrochim. Acta, 2009, 54, 5363-5367.

33. S. T. Myung, K. Amine and Y. K. Sun, J. Power Sources, 2015, 283, 219-236.

34. B. F. Pan, Z. X. Feng, N. Y. Sa, S. D. Han, Q. Ma, P. Fenter, J. T. Vaughey, Z. C. Zhang and C. Liao, Chem. Commun., 2016, 52, 9961-9964.

35. C. Ling and F. Mizuno, Chem. Mater., 2013, 25, 3062-3071.

36. M. Cabello, R. Alcantara, F. Nacimiento, G. Ortiz, P. Lavela and J. L. Tirado, Crystengcomm, 2015, 17, 8728-8735.

37. N. N. Sinha and N. Munichandraiah, Electrochem. Solid-State Lett., 2008, 11, F23-F26.

38. M. F. Rahman and D. Gerosa, Optoelectronics and Advanced Materials-Rapid Communications, 2015, 9, 1204-1207.

39. R. A. DiLeo, Q. Zhang, A. C. Marschilok, K. J. Takeuchi and E. S. Takeuchi, Ecs Electrochemistry Letters, 2015, 4, A10-A14.

40. M. Rybicki and E. Hawlicka, Chem. Phys., 2012, 400, 79-85.

41. A. Chatterjee, M. K. Dixit and B. L. Tembe, The Journal of Physical Chemistry A, 2013, 117, 8703-8709.

42. W. Choi and A. Manthiram, J. Electrochem. Soc., 2006, 153, A1760-A1764.

43. X. C. Xiao, D. Ahn, Z. Y. Liu, J. H. Kim and P. Lu, Electrochem. Commun., 2013, 32, 31-34. 